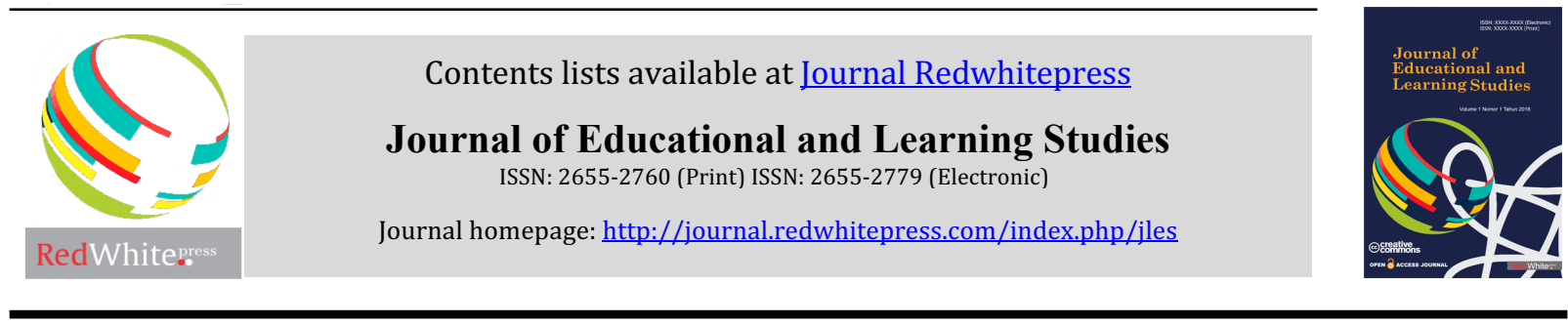

\title{
The Correlation Between Career Planning, Attribution and Students Learning Motivation
}

\author{
Rendi Samosir ${ }^{1}$, Herman Nirwana ${ }^{1}$, Alizamar $^{1}$ \\ ${ }^{1}$ Universitas Negeri Padang
}

\begin{tabular}{l}
\hline \hline Article Info \\
\hline Article history: \\
Received Jan $19^{\text {th }}, 2020$ \\
Revised Feb $23^{\text {th }}, 2020$ \\
Accepted Mar $21^{\text {th }}, 2020$ \\
\hline
\end{tabular}

\section{Keyword:}

Career Planning

Attribution

Learning Motivation

\begin{abstract}
Learning motivation has an important role in student learning process. The objectives of this research are to describe students career planning, to describe student attribution, to describe students learning motivation, to examine the correlation between career planning and students learning motivation, to examine the correlation between attribution and students learning motivation, and to examine the correlation between career planning and students learning motivation. The research uses correlational descriptive type of quantitative method. The population of research are 435 students of Curriculum and Education Technology Major in State University of Padang. A sample of 208 students was chosen by proportional random sampling technique. The instruments used were career planning, attribution, and students learning motivation. Data were analyzed by descriptive statistics, linear regression and multiple regression. The research findings show that 1) in general students already have a good career planning 2) student attribution is in the middle category 3) student learning motivation is in high category 4) there is a positive significant correlation between career planning and student learning motivation 5) there is a positive significant correlation between attribution and learning motivation 6) there is a positive significant correlation between career planning and attribution with student learning motivation, and (7) the implication of this research findings can be used as a feedback for making a program of guidance and counseling service which can improve career planning, attribution, and students learning motivation.
\end{abstract}

(C) 2020 The Authors. Published by Redwhitepress.

This is an open access article under the CC BY-NC-SA license

(https://creativecommons.org/licenses/by-nc-sa/4.0/

\section{Corresponding Author:}

Rendi Samosir,

Universitas Negeri Pdang

Email: ren.sam1234@gmail.com

\section{Introduction}

Education is important for everyone. To have education in a university is a very precious opportunity that must be treasured well. In a nation context, education holds an important role in producing people with good quality and integrity. The goal of national education in the constitution No. 20 Year 2003, Chapter 1 verse (1) about the System of National Education states that education is a deliberate and planned effort in creating learning environment and process for the students to actively develop their own potentials to have religious-spiritual strength, self-control, personality, intellect, good moral and skills that are useful for themselves, their community, and the nation.

Parallel to that, students as the reformation agents of the nation are expected to become creative learners who keep up with more developed progress which are done through learning process. According to Sardiman (2012), "Learning is a change of behavior or appearance through with a set of activities for example 
by reading, observing, listening, modeling, and so on." Furthermore, Romine (Hamalik, 2009) states that learning is a process done through a set of experiences which results in a modification of the previous behaviors.

Maslow (McClelland, 1987) says that motivation is related with needs. To survive, people need food, water and sex in order to preserve their descendants. After their needs are met, they will think of ways to protect themselves from any kinds of disturbances, dangers or other bad weather. When the need for their safety is fulfilled, they will comfortably build close relationships with other human beings. Generally, people will never be satisfied in fulfilling their life needs, they will always try to attain more.

According to Asrori (2009), motivation can be defined as an impulse arising from a person to take action with a particular goal and efforts that can make a person or group of people to do something in order to achieve goals. From the two definitions above, then motivation can be divided into two types, namely motivation from within a person (intrinsic motivation) and motivation from outside (extrinsic motivation). Learning motivation is very needed so that failure in learning will not happen and student abilities can be developed optimally.

Research findings of Rahmi (2012) in UNP's Pembangunan Laboratorium Secondary School about "Self-Concepts, Learning Motivation, Students Skipping and Their Implications for Guidance and Counseling Services." The results showed that $69.2 \%$ of students had a weak learning motivation. Attention and desire to learn is lacking which can be seen from the low motivation of students to do homework and exercises at school such as lazy in studying, lack of responsibility in doing homework given by the teacher and not being able to manage studying schedules.

Based on an observation done by the researcher on 12 December 2014, the result showed that there were still students with low learning motivation. Several phenomena that appeared were that there were students cheating on exams, busier in being involved in organizations outside the campus and choosing the major in curriculum and education technology because they could not get their preferred first choice. Furthermore, a lecturer informed that there are students who are less persistent in studying based on the collected assignments given and an issue of self-reliance in studying.

Ideally, students should have self-reliance in order that they can follow the learning process well and get an optimum result. According to Sardiman (2012), students with high learning motivation have the following characteristics: (1) Diligent in doing assignments, (2) persevering, (3) showing interest, (4) self-reliant, (5) easily getting bored with mundane tasks, (6) being able to defend his or her opinion, (7) not easily forego one's conviction and (8) happy to find and solve problems.

One of the factors that influences learning motivation is attribution. According to Santrock (2010), attribution is something that can increase learning motivation, because it is an attempt to understand one's behavior or performance.

Schrodt \& Witt (LaBelle \& Martin, 2014) say that, "Attribution theory is a person perception theory that is particularly useful for understanding student perceptions of instructor behavior, because it deals with the nonsense ways in which individuals attempt to answer the "why" questions underlying human behavior". Also, Weiner (Vialle \& Woodcock, 2015) states that attribution is a summary drawn by an individual to explain why one action or incident happens.

Boyle's research findings (2014) about "Understanding perceptions of stuttering among school-based speech-language pathologists: an application of attribution theory" shows that only $7 \%$ of public believe stutter could have neurogenic cause and $45 \%$ believe it to have psycho-genetic cause. Among school teachers in the USA, $5 \%$ agree that stutter is caused by psychological problem and $48 \%$ disagree. Two things that are often understood in the concept of attribution include the dimensions of the ability to control (desired) and the ability to control offset (undesirable). The results show that a significant correlation was found between several variables. Desired and undesired control abilities are both negative when it comes to willingness to help and sympathy and both are positive for anger. Biological attribution is positive when it relates to sympathy, while it is negative when it is related to desired and undesired control abilities.

Weiner (Elliot, Kratochwill \& Travers, 1996) believes that when accomplishment is being triggered, we tend to attribute our performance to one of the four aspects which are: (1) ability, (2) effort, (3) difficulty of the task, and (4) fate. With this attribution, ability and effort are the most important. Thus, success is attributed for high ability and effort, while failure can be seen as the result of low ability and effort.

According to Hurlock (1980), student time is the time when an individual enters the period of early adulthood (18 to 40 year old). Following that, Hurlock (1980) explains that one of the tasks of early adulthood 
development is to get a decent job, so at this time an individual should start thinking about future plans related to careers and what job one should start with after graduating from university.

Another factor that plays a role in students learning motivation is career planning. One of the important aspects in the stages of career development process is, having a career planning will help someone to design a career in the future. This is in line with the opinion of Dillard (1985) that before starting a career, a person needs to assess the needs and interests make plans to achieve career goals, and then work to achieve those goals. Furthermore, Niles \& Harris (2014) suggested that career planning is an assessment process to help individuals at a certain point in time to recognize interests and skills in order to identify appropriate educational or vocational choices as an advanced stage in career development.

Based on the results of Sukmasuci's research (2013), 79\% of junior high school students in grade IX are still confused in choosing high schools, $71 \%$ are still unable to overcome the arising problems when choosing their high schools, and $72 \%$ have not dared to express ideas or opinions about the high school that they want. Bardick, Bernes, Magnusson \& Witko (2005) explain that career planning is very important for students.

Students career planning often faces obstacles both from themselves or from external, therefore efforts are needed so that students understand their potential and confidently plan their future. According to Zlate (Antoniu, 2010), an individual career planning can be traced through 5 steps, as follows: (1) Self-assessment, (2) Exploring opportunities, (3) Making decisions and setting goals, (4) Planning , (5) Pursuit of achivement goals, actions by an individual for successes and failures and make decisions to maintain or change his career.

Based on the description of the problems above, the researcher is interested in studying about "The correlation between career planning, attribution and learning motivation."

\section{Method}

This research quantitative method with correlational method. The research population were students of Curriculum and Education Technology Major from Education faculty in State University of Padang who were registered at first semester (Batch, 2018), third semester (Batch, 2017), and fifth semester (batch 2016), with a total of 435 students. This research was conducted from December 12th 2018 until December 16th 2018.

The sampling technique in this research used proportional random sampling method, meaning that the number of samples in each stratum is proportional to the number of population members in each stratum population (Yusuf, 2013). The sample in this research were 208 people out of 435 students because the technique used to determine the amount of sample was the proportional random sampling. Slovin formula was used to determine the sample size. The model instrument used was questionnaire with Likert Scale Model. Based on the analysis result of attribution instrument, 38 out of 44 items are valid. The reliability of variable is 0.96. The data analysis used the Rasch model because it can measure the accuracy of each item better and we can also see the reliability of the respondents. So, by using Rasch analysis model, we can predict the item and the respondent simultaneously.

\section{Results and Discussions}

The results of the data processing of student career planning show that the majority of student career planning is in the High $(\mathrm{H})$ category with a total frequency of 129 students or $62.02 \%$ in percentage. Followed by students in the category of Very High ( $\mathrm{VH}$ ) with a total frequency of 49 students or $23.56 \%$ in percentage. Most of the other students are in the Medium (M) category with a frequency of 30 students or $14.42 \% .53$

The results of data processing of attribution show that the majority of student attribution is in the Medium (M) category of 59.14\% with a total frequency of 123 students, High $(\mathrm{H})$ category of $37.98 \%$ with a total frequency of 79 students. Then, students with Very High (VH) category of $1.92 \%$ with a total frequency of 4 persons. There are students with Low category of $0.96 \%$ with a total frequency of 2 persons.

The results of student learning motivation show that the majority of students have high learning motivation of $71.16 \%$, some other students in very high category of $20.67 \%$ and the rest with medium category of $8.17 \%$.

\section{First Hypothesis Test}

Table 1. Analysis Result of Correlation between Career Planning $\left(\mathrm{X}_{1}\right)$ and Learning Motivation (Y)

\begin{tabular}{|c|c|c|c|}
\hline Variable & $\mathbf{R}$ & $\mathbf{r}_{\text {Square }}$ & Sig. \\
\hline $\mathrm{X}_{1}-\mathrm{Y}$ & 0.385 & 0.148 & 0.000 \\
\hline
\end{tabular}


Based on Table 1, the value of $\mathrm{r}$ is 0.385 which shows the correlation between career planning and learning motivation. Then, the value of rSquare (r2) of 0.148 means that career planning has a correlation with learning motivation of $14.80 \%$ with a significance level of 0.000 smaller than 0.05 . That means career planning contributes $14.80 \%$ to learning motivation dan $85,20 \%$ is influenced by other variables.

\section{Second Hypothesis Test}

Table 2. Results of Simple Linear Regression Analysis Attribution (X2) towards Learning Motivation (Y)

\begin{tabular}{|c|c|c|c|}
\hline Variable & $\mathbf{r}$ & r $_{\text {square }}$ & Sig. \\
\hline $\mathrm{X}_{2}-\mathrm{Y}$ & 0.321 & 0.103 & 0.000 \\
\hline
\end{tabular}

Based on Table 2, it shows that the value of $\mathrm{r}$ is 0.321 , which shows the correlation between attribution and learning motivation. Then, the value of rSquare ( $\mathrm{r} 2)$ of 0.103 means attribution has a correlation with learning motivation of $10.30 \%$. That means attribution contributes $10.30 \%$ to learning motivation.

\section{Third Hypotesis Test}

Table 3. Correlation Analysis Results of Career Plannning $\left(\mathrm{X}_{1}\right)$ and Attribution $\left(\mathrm{X}_{2}\right)$ with Learning Motivation (Y)

\begin{tabular}{|c|r|l|c|}
\hline Variable & $\mathbf{r}$ & $\mathbf{r}_{\text {Square }}$ & Sig. \\
\hline $\mathrm{X}_{1}, \mathrm{X}_{2}-\mathrm{Y}$ & 0.414 & 0.172 & 0.000 \\
\hline
\end{tabular}

Based on Table 3 , it shows that the $r$ value of 0.414 which indicates career planning and attribution has a significant correlation with learning motivation. Then, the rSquare (r2) value of 0.172 means that both career planning and attribution contribute together to learning motivation by $17.20 \%$.

\section{Discussion}

Based on the results of the hypothesis testing which has already been described, the career planning and attribution have a correlation with the students learning motivation. That means, the higher the career planning and attribution, the higher the learning motivation that the students achieve. In the following sections, there will be explanation for each variable examined in this research.

\section{Career Planning}

The research results show that students career planning is in the high category, with an average score of 132.50 of a percentage of respondents at $80.33 \%$. The results of the research conducted prove that one of the factors that influences learning motivation is career planning.

For students, career planning is important because it can be used as a guide in making decisions about their careers in the future. In line with the opinion of Bardick, Bernes, Magnusson \& Witko (2004) that career planning is very important since adolescence, since at that very time they start to explore their own capabilities.

According to Andersen \& Vandehey (2012), career information is important in career planning. The students also need to realize there are various kinds of information about occupation, education and training, employment, and economics. Indeed, it is necessary for the students to realize that career information is important in their career planning stage, therefore it is very fundamental for the students to determine their attitudes in exploring career information obtained from various sources.

\section{Attribution}

The research results show that the student attribution is in the medium category, with an average score of 128.67 of a percentage of respondents at $67.72 \%$. The results of research conducted prove that another factor that influences learning motivation is attribution.

Heath and McDermott (Kriyantono, 2014) say that attribution theory can be described with several assumptions, e.g.: 1) Individuals tend to want to know the source of what they see. 2) Individuals use systematic processes in explaining a behavior. 3) Once an attribute is created, that attribute influences subsequent feeling and behavior. 4) Individuals have a reason to build their impressions toward others.

\section{Learning Motivation}

The research results show that students learning motivation is in the high category, with an average score of 116.40 of a percentage of respondents at $77.60 \%$. According to Hamalik (2008), motivation is one of the factors determining effective learning. 
Students who are motivated in learning are able to prepare themselves well before studying, such as reading textbooks, doing homework, spending more time in studying, persevering in learning, encouraged and moved to start activities of their own volition, completing assignments on time, and not giving up easily when facing difficulties in doing university assignments.

Students who have high learning motivation tend to be able to adjust well. According to Sardiman (2011), there are 3 functions of motivation, e.g.: encouraging students to do something, as a moving factor to release the energy. Motivation in this case is the driving force of every activity they will be doing. Deciding the direction of the change, which is toward their targeted goals. Motivation can provide direction and activities that must be done in accordance with the formulated objectives.

\section{Correlation between Career Planning and Learning Motivation}

The results of the research of career planning with learning motivation show that there is a positive and significant correlation between both variables. This finding is obtained based on a series of data analysis which shows that career planning correlates with learning motivation by $10.20 \%$. According to Issacson (1986), individuals who plan their career will go through five stages starting from (1) self-understanding, (2) doing exploration, (3) making decisions, (4) making preparations to enter the marketplace, and (5) entering the real marketplace. Someone who has passed these 5 stages will be motivated to have high learning motivation.

\section{Correlation of Attribution with Learning Motivation}

The result of the research of attribution with learning motivation indicate that there is a positive and significant correlation between both variables. This finding is obtained based on a series of data analysis which shows that attribution correlates with learning motivation by $14.80 \%$.

The impression resulted from this case occurs in 3 stages, e.g. observing behaviors, determining whether the behavior is done intentionally or not, and categorizing the behavior as one that is driven by internal or external motivation (Kriyantono, 2014).

\section{Correlation between Career Planning and Attribution with Learning Motivation}

The results of the research of career planning and attribution with learning motivation indicate that there is a positive and significant correlation. This finding is obtained based on a series of data analysis which show that career planning and attribution correlate with learning motivation by $17.10 \%$. That means, the correlation between career planning and attribution with learning motivation is $17.10 \%$, while the remaining $82.10 \%$ is explained by other variables not examined in this study. Therefore, that explains both career planning and attribution are factors which have a positive influence on learning motivation.

Based on the above data, it can be concluded that if the students have good career planning and good attribution, it will have a positive impact on their learning motivation and vice versa if the students do not have good career planning and attribution, it will have a negative impact on learning motivation..

\section{Conclusions}

In general, the students career planning is in the high category. As per indicator it is also categorized as good. This means, in general students already have a good career planning. Students' attributions are in the medium category. This means, students' attribution needs special attention to be improved. Students' learning motivation is classified in the high category. This means, that students' learning motivation needs to be maintained and improved. There is a significant positive correlation between career planning and learning motivation. There is a significant positive correlation between attribution and learning motivation. There is a significant positive correlation between both career planning and attribution with students' learning motivation. These results explain if both career planning and attribution are high, then learning motivation tends to be high. Based on the results of data analysis, it can be interpreted that students' learning motivation is influenced by $17.10 \%$ career planning and attribution.

\section{References}

Andersen, P. \& Vandehey, M. 2012. Career Counseling and Development in Global Economy2 ${ }^{\text {nd }}$ Ed. USA: Brooks/Cole

Antoniu, E. 2010. "Career Planning Process and It's Role in Human Resource Management”. Tesis. Petroşani: Economi in annals of the university of petroşani.

Asrori, M. 2009. Psikologi Pembelajaran. Bandung: Wacana Prima 
Bardick, A., D., Bernes, K., B., Magnusson, K., C., \& Witko, K., D. 2005. "Senior High Career Planning: What student want". Journal of Educational Enquiry, 6 (1).

Bardick, A., D., Bernes, K., B., Magnusson, K., C., \& Witko, K., D. 2004. "Junior High Career Planning: What student want". Canadian Journal of Counselling/Revue canadienne de counseling,38 (2).

.Boyle, M. P. 2014. Understanding perceptions of stuttering among school-based speech-language pathologists: An application of attribution theory. (Online), Volume 52, 143-155, (http://isiarticles.com/bundles/Article/pre/pdf/35436.pdf, diakses 2 September 2018)

Dillard, J. M. 1985. Lifelong Career Planning. Ohio: E. Charles Merrill Publishing Company.

Elliot, S. N., Kratochwill, T. R., Littlefield, J., \& Travers, J. F. 1996. Educational Psychology: Effective teaching, effective learning. Singapore: McGraw-Hill Book Co.

Hamalik, O. 2009. Dasar-dasar Pengembangan Kurikulum. Bandung: Remaja Rosdakarya.

Issacson, L. E. 1986. "Career Information in Counseling and Career Development (Fourth Edition)". Boston: Allyn and Bacon, Inc.

Kriyantono, R.2014. Teori Public Relations Perspektif Barat \& Lokal: Aplikasi Penelitian \& Praktek. Jakarta: Kencana.

LaBelle, S., \& Martin, M. M. (2014). Attribution Theory in the Collage Classroom: Examining the Relationship of Student Attributions and Instructional Dissert. Communication Research Report, 110.

McClelland, D. C. 1987. Human Motivation. Cambridge: University Press

Niles, S. G. \& BowlsBey, J. H. 2014. Career Development Interventions in the $21^{\text {st }}$ Century (Fourth Ed.) USA: Pearson

Ormrod. J. E. 2001. Educational Psychology: Developing learner (fifth edition). New Jersey: Pearson Education, Inc.

Rahmi, A. 2012. "Konsep Diri, Motivasi Belajar Siswa Membolos dan Implikasinya terhadap Layanan Bimbingan dan Konseling (Studi terhadap Siswa SMP Laboratorium UNP). Tesis tidak diterbitkan. Padang: Program Studi Bimbingan dan Konseling Pascasarjana UNP.

Santrock, J. W. 2004. Psikologi Pendidikan. Terjemahan oleh Tri Wibowo. 2010. Jakarta: Kencana.

Sardiman. 2012. Interaksi \& Motivasi Belajar Mengajar. Jakarta: Raja Grafindo Persada.

Yusuf, A. M. 2013. Metode penelitian kuantitatif, kualitatif, dan penelitian gabungan. Padang: UNP Press. 